\section{Antidesiccants Applied to Packaged Rose Plants Affect Growth and Field Performance}

\author{
Ursula K. Schuch \\ Botany and Plant Sciences Department, University of California, Riverside, \\ CA 92521 \\ John F. Karlik \\ Cooperative Extension, University of California, 1031 South Mount Vernon \\ Avenue, Bakersfield, CA 93307
}

Charlene Harwood

Bear Creek Production Company, P.O. Box 280, Wasco, CA 93280

Additional index words. postharvest, transplanting, antitranspirants, hot wax, Rosa

\begin{abstract}
Moisture loss from bare-root plants during postharvest handling and storage can have a significant impact on plant survival and growth during establishment. Three filmforming antitranspirants and hot wax were applied to bare-root roses (Rosa) packaged after harvesting from the field and before 13 weeks of $-2 C$ storage to determine effects on vegetative growth and flowering. Subsequently, during 15 days under simulated display conditions ( 22 to 32C), plants treated with hot wax resumed growth at the fastest rate compared to control or antitranspirant treatments. Hot-wax-treated plants remained at an advanced phenological stage compared to the other plants for 2 weeks following transplanting in the field. For the remaining 10 weeks of the experiment, vegetative growth and flowering development were similar for all treatments. More than $60 \%$ of the plants treated with hot wax developed moderate to severe cane damage and plant dieback. Less than $20 \%$ of the antitranspirant-treated plants were damaged. A laboratory experiment confirmed that hot wax treatment was most effective; it reduced weight loss from stem sections by $85 \%$ relative to the control. The other antitranspirants reduced weight loss by $27 \%$.
\end{abstract}

California produces 30 to 40 million bareroot rose plants each year at a value of more than 35 million dollars, comprising two-thirds of the United States' production. Roses destined for home gardens or the landscape are commonly dug in the field in late fall or winter and held as bare-root plants in cold storage until shipping. The duration of cold storage can last from a few days to several months, depending on the time of harvest and the beginning of the growing season at the final destination.

Desiccation of bare-root nursery stock during postharvest handling, cold storage, and reestablishment can have a significant effect on establishment and growth of plants. Transplant success is highest when plants are lifted at a time when they are most tolerant to desiccation (Coutts, 1981; Englert et al., 1993; Murakami et al., 1990; Ritchie et al., 1985) and when water loss is minimized during stor-

Received for publication 15 Apr. 1994. Accepted for publication 31 Aug. 1994. We acknowledge the Univ. of California Agricultural Experiment Station for their support of this research. Reference to commercial products does not imply endorsements by the authors. The cost of publishing this paper was defrayed in part by the payment of page charges. Under postal regulations, this paper therefore must be hereby marked advertisement solely to indicate this fact. age. Packing materials, such as polyethylene, cardboard lined with polyethylene or wax paper (Lefevre et al., 1991), or application of film-forming compounds on the shoots (Englert et al., 1993; Toy and Mahlstede, 1959), provide effective barriers to moisture loss.

Roses are more prone to desiccation compared to other woody nursery stock (Toy and Mahlstede, 1959). For more than half a century, nursery growers have protected rose canes by coating them with hot wax before cold storage or shipping (Foret, 1951; Lyle, 1955; Tukey and Brase, 1931; Welch and Cameron, 1990). In addition, canes may be treated with antitranspirants (Welch and Cameron, 1990) or by sealing roots in polyethylene bags with moist packing material. Rose canes treated with paraffin grew better and fewer died than those not treated with an antitranspirant before winter storage (Tukey and Brase, 1931). Lyle (1955) confirmed that hot wax treatment was not detrimental to vegetative and reproductive growth when canes were exposed from 1 to 6 sec to wax between 77 and 98C. However, damage on older waxed canes was observed in the field (Lyle, 1955).

The objective of this experiment was to determine the efficacy of several antitranspirants under laboratory conditions and to determine if these antitranspirants applied before prolonged cold storage affected vegetative growth and flowering of roses during establishment in the landscape.
Laboratory study. Stems of 'White Delight' roses were cut to $10 \mathrm{~cm}$ long and cut ends were sealed with melted wax (85C). 'White Delight' was selected for this experiment because of the generally weaker canes and higher susceptibility to desiccation during postharvest handling compared to other cultivars (unpublished). The antitranspirants Alcoprint PBA and Glascol LS20 (Allied Colloids, Suffolk, Va.), both containing proprietary polymers, and Moisturin (Burke's Protective Coatings, Washougal, Wash.), a latex emulsion, were prepared according to the manufacturers' recommendations. Aqueous solutions at concentrations of 1:20 (v/v) for Alcoprint or Glascol and 1:3 (v/v) for Moisturin were prepared; petroleum wax (General Purpose Rose Bush Wax; IGI Boler, Wayne, Pa.) was melted to 85C. Six stem sections were dipped for $3 \mathrm{sec}$ in each treatment (control sections were dipped in water) and placed on a screen on a laboratory bench at $22 \pm 2 \mathrm{C}$ and $20 \% \pm 5 \%$ relative humidity. Weight loss was determined gravimetrically at 24-h intervals over $96 \mathrm{~h}$ and calculated based on the surface area of each stem section. Thickness of the hot wax or antitranspirant coating on stem sections was measured with an Ultra-Cal II electronic caliper (Fowler, Newton, Mass.).

Shadehouse and field study. 'White Delight' bare-root roses growing in Bakersfield, Calif., were lifted in the field and held in temporary cold storage in polyethylene-lined boxes at $2 \mathrm{C}$ and relative humidity near saturation inside the box for 6 weeks. Plants were taken out of storage on $14 \mathrm{Jan} .1993$ and shoots and roots pruned to 30 and $15 \mathrm{~cm}$, respectively. Plants were washed to remove all soil debris from canes and roots. Roots were then packed with moist sawdust and wrapped with polyethylene bags to minimize dehydration. Twenty-five plants were assigned randomly to a treatment and canes were dipped in antitranspirants or wax as described above. Control plants received no further treatment. After the antitranspirants had dried, plants were placed in shipping boxes, sealed, and stored at -2C. Plants were kept for 13 weeks in storage to later test establishment in the field under warmer and more stressful conditions.

Plants were removed from storage and placed upright for 3 weeks on the ground in a shadehouse to simulate display conditions at a retail store. Maximum temperatures, as measured at the Shafter California Irrigation Management Information System Station, $5 \mathrm{~km}$ from the experimental location, ranged from 22 to $32 \mathrm{C}$; minima were 6 to $12 \mathrm{C}$; and the average relative humidity ranged between $38 \%$ and $57 \%$. On 5 May, when roses were transplanted into the field, the number of new shoots and average shoot length were recorded. Plants were irrigated regularly and fertilized once a month with one teaspoon $(\approx 4.4 \mathrm{~g})$ of Armstrong Roses E-Z Grow Fertilizer (15N30P-15K) (Salinas, Calif.). Phenological development was rated every 3 to 4 days by visually assessing shoot elongation, leaf growth, and flower bud development. The 
following rating system was used: $0=$ no growth, 1 = buds swollen, 2 = shoots elongating, $3=$ leaves unfurling, $4=$ leaves expanded, $5=$ shoots 5 to $10 \mathrm{~cm}$ long, $6=$ flower bud, 7 $=$ color in flower bud. New vegetative growth developing after cold storage was harvested on 28 July 1993 and dry weights were determined. On the same day, cane damage was rated visually as the percentage of the total cane affected by dieback.

Plants were arranged in a completely randomized block design with five plants of each treatment in a block. Analysis of variance and mean treatment comparisons and contrasts were calculated with the statistical package SAS (SAS Institute, 1988).

\section{Results and Discussion}

Laboratory study. Hot wax most effectively minimized weight loss from stem sections (Table 1). Wax-treated stem sections had lost $85 \%$ less weight than the control after 96 $\mathrm{h}$. During the first $24 \mathrm{~h}$ of drying, stem sections treated with Moisturin lost less weight than those treated with Glascol or Alcoprint, but the three materials performed similarly for the remainder of the study (Table 1). The antitranspirant-treated stems lost $27 \%$ less weight than the control, but were much less effective than hot wax, and not significantly different from the control after $96 \mathrm{~h}$.

Hot wax formed the thickest coating $(0.34$ $\mathrm{mm}$ ) on the stem sections, providing an effective physical barrier to moisture loss. Waxed cane sections had lost less weight in 17 days than nontreated sections in 4 days (Toy and Mahlstede, 1959). Of the antitranspirants, Moisturin resulted in a slightly thicker coating $(0.03 \mathrm{~mm})$, though not significantly different from Glascol and Alcoprint $(0.02 \mathrm{~mm})$. Englert et al. (1993) found that the performance of Moisturin was improved when the compound was used at lower dilution rates, which increased coverage.

Shadehouse and field study. Buds on canes of all treatments were swollen when plants were removed from storage at $-2 \mathrm{C}$ after 13 weeks (Fig. 1). Within 1 week of display conditions, shoots were elongating on plants treated with hot wax. Plants treated with antitranspirants or water resumed growth more slowly. After 3 weeks in the shadehouse, antitranspirant- or water-treated plants had swollen buds and elongating shoots, while leaves were already unfurled or expanding on hot-wax-treated plants. Results from this and previous work (Toy and Mahlstede, 1959; Welch and Cameron, 1990) suggest that hot wax treatment is more effective in preventing moisture loss from the plants during storage and display than other treatments studied. Higher moisture content of the canes may result in more rapid recovery and more vigorous vegetative growth once plants are removed from cold storage and following transplanting.

After 3 weeks display in the shadehouse, before the roses were transplanted to the field, hot-wax-treated plants had 3 to 4 times as many shoots and 3 to 6 times longer new

Table 1. Weight loss of rose stem sections treated with various antidesiccants. Ambient conditions in the laboratory were $22 \pm 2 \mathrm{C}$ and $20 \% \pm 5 \%$ relative humidity.

\begin{tabular}{lrrrrr}
\hline \hline & \multicolumn{5}{c}{$\begin{array}{c}\text { Wt loss }\left(\mathrm{mg}^{\circ} \mathrm{cm}^{-2}\right) \\
\text { hours after treatment }\end{array}$} \\
\cline { 2 - 6 } Antidesiccant & $0-24$ & $25-48$ & $49-72$ & $73-96$ & Total \\
\hline None & $63.7 \mathrm{a}^{\mathrm{z}}$ & $30.1 \mathrm{a}$ & $17.0 \mathrm{a}$ & $13.3 \mathrm{a}$ & $124.1 \mathrm{a}$ \\
Hot wax & $5.8 \mathrm{c}$ & $4.6 \mathrm{~b}$ & $3.6 \mathrm{~b}$ & $4.0 \mathrm{~b}$ & $18.0 \mathrm{~b}$ \\
Moisturin & $38.9 \mathrm{~b}$ & $22.2 \mathrm{a}$ & $12.8 \mathrm{a}$ & $9.9 \mathrm{ab}$ & $83.8 \mathrm{a}$ \\
Glascol & $54.2 \mathrm{ab}$ & $22.8 \mathrm{a}$ & $11.1 \mathrm{a}$ & $8.1 \mathrm{ab}$ & $96.3 \mathrm{a}$ \\
Alcoprint & $53.8 \mathrm{ab}$ & $20.6 \mathrm{a}$ & $10.5 \mathrm{ab}$ & $7.4 \mathrm{ab}$ & $92.2 \mathrm{a}$ \\
Probability level of contrasts & & & & & \\
$\quad$ Wax vs. antitranspirant & 0.0001 & 0.0001 & 0.0009 & 0.024 & 0.0002 \\
Control vs. all & 0.0008 & 0.0113 & 0.0011 & 0.003 & 0.0004 \\
$\quad$ Wax vs. all & 0.0001 & 0.0001 & 0.0001 & 0.004 & 0.0001 \\
Control vs. antitranspirant & 0.0042 & 0.0267 & 0.0132 & 0.015 & 0.0161 \\
\hline
\end{tabular}

${ }^{2}$ Mean separation within columns at $P \leq 0.05$ by Tukey's Studentized Test.

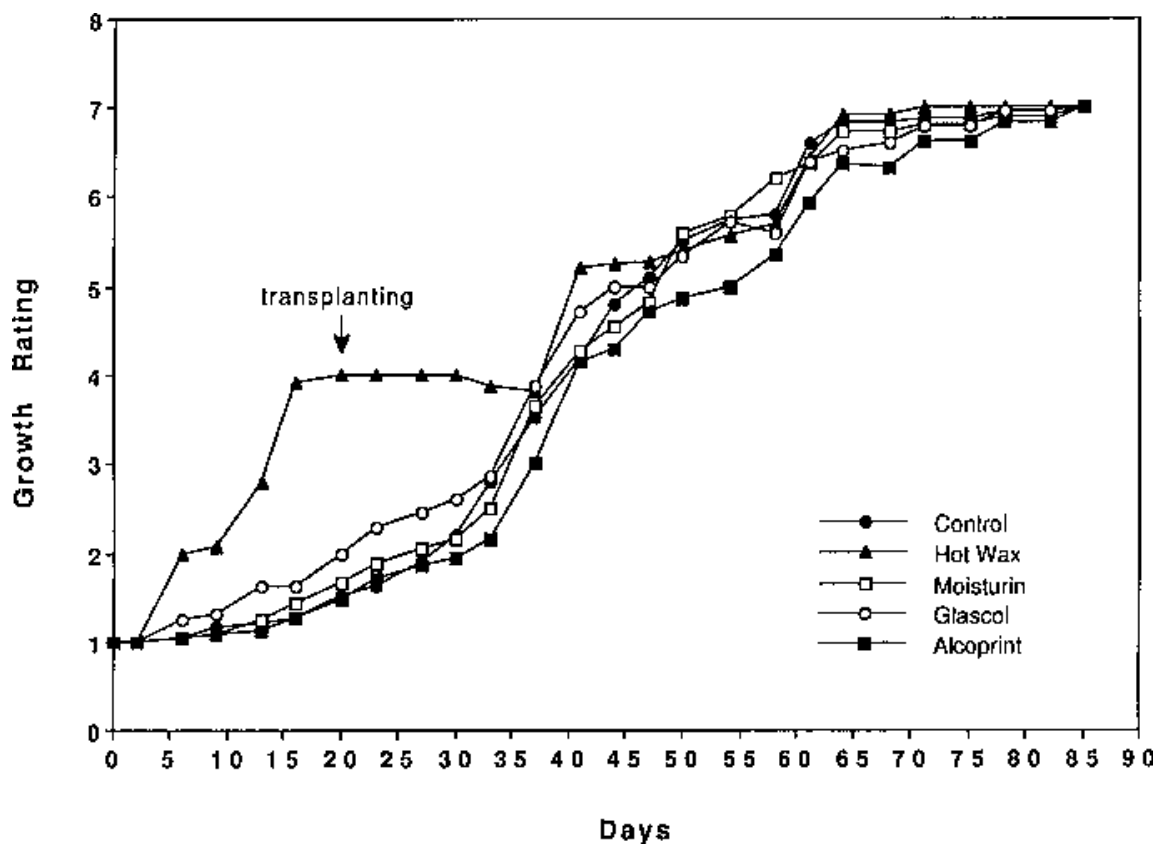

Fig. 1. Average growth ratings of 'White Delight' roses during display in the shadehouse for 3 weeks before transplanting and during 10 weeks of establishment in the field. Plants were treated with antidesiccants (hot wax, Moisturin, Glascol, or Alcoprint) and had been stored at $-2 \mathrm{C}$ for 13 weeks. Growth ratings: $0=$ no growth, $1=$ buds swollen, $2=$ shoots elongating, $3=$ leaves unfurling, $4=$ leaves expanded, $5=$ shoots 5 to $10 \mathrm{~cm}$ long, $6=$ flower bud, $7=$ color in flower bud.

shoots than those of any other treatment (Table 2). Plants treated with hot wax continued to grow faster than the other plants until 14 days after transplanting (Fig. 1), and growth ratings for wax-treated plants were also higher $(P \leq$ 0.05 ) during this period. A similar increase in the number of lateral breaks was observed for waxed roses compared to nontreated ones during simulated marketing at $23 \mathrm{C}$ and following transplanting (Welch and Cameron, 1990). Within 42 days after transplanting, plants from all treatments had set flower buds, and subsequently all undamaged plants reached anthesis (Fig. 1). All plants flowered continuously until shoots were harvested at the end of July.

When plants were harvested for dry weight, $60 \%$ of the wax-treated roses had suffered from mild to severe cane dieback or complete plant dieback (Table 3). One-third of the control plants and $<20 \%$ of the plants treated with antitranspirants were affected by cane or plant dieback (Table 3). Dry weight of new shoots, therefore, was lowest for hot-wax-treated plants, except for those dipped in Alcoprint (Table 2). One-fifth of the latter was affected with cane damage.

Although plants treated with wax developed shoots at a faster rate, phytotoxicity symptoms became apparent 17 days after plants were transplanted into the field and exposed to full sunlight. Symptom development coincided with days up to $32 \mathrm{C}$ in the field. When the canes were exposed to high temperatures and wax remained on the cane, bubbles started to form under the wax, probably from transpiration. Blocking the cooling effect of transpiration could cause overheating of plant tissue (Davies and Kozlowski, 1974) and lead to cambium death. Ultraviolet solar radiation may play a secondary role in causing the damage. Brown or black tissue was observed most frequently on southwest exposure of the canes. In earlier field studies in Texas, Lyle (1955) observed damage to rose canes from hot wax; however, foliage shading the waxed part from direct sunlight seemed to diminish 
Table 2. Number and length of new shoots of 'White Delight' roses at the time of transplanting and dry weight of vegetative shoots after 12 weeks in the field.

\begin{tabular}{lccr}
\hline & \multicolumn{2}{c}{ New shoots } & Length \\
\cline { 2 - 4 } Antidesiccant & $\begin{array}{c}\text { Count } \\
(\text { no. })\end{array}$ & $1.0 \mathrm{a}$ & $\begin{array}{c}\text { Dry wt } \\
(\mathrm{g})\end{array}$ \\
\hline None & $2.1 \mathrm{a}^{\mathrm{z}}$ & $6.0 \mathrm{~b}$ & $48.8 \mathrm{a}$ \\
Hot wax & $11.7 \mathrm{~b}$ & $1.0 \mathrm{a}$ & $30.1 \mathrm{~b}$ \\
Moisturin & $2.5 \mathrm{a}$ & $1.8 \mathrm{a}$ & $48.8 \mathrm{a}$ \\
Glascol & $4.2 \mathrm{a}$ & $0.9 \mathrm{a}$ & $43.8 \mathrm{a}$ \\
Alcoprint & $2.2 \mathrm{a}$ & & $37.7 \mathrm{ab}$ \\
Probability level of contrasts & & 0.0001 & 0.011 \\
Wax vs. antitranspirant & 0.0001 & 0.0014 & 0.156 \\
Control vs. all & 0.0011 & 0.0001 & 0.006 \\
Wax vs. all & 0.0001 & $\mathrm{NS}$ & $\mathrm{NS}$ \\
Control vs. antitranspirant & NS & & \\
\hline
\end{tabular}

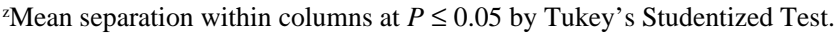

Table 3. Percentage of 'White Delight' roses showing various levels of cane dieback after 12 weeks in the field. Plants had been treated with various antidesiccants, stored at $-2 \mathrm{C}$ for 13 weeks, and displayed in a shadehouse for 3 weeks before transplanting.

\begin{tabular}{lcccr}
\hline & \multicolumn{4}{c}{ Dieback of canes/plant (\%) } \\
\cline { 2 - 5 } Antidesiccant & 0 & $1-50$ & $51-99$ & 100 \\
\hline None & $68 \mathrm{ab}^{\mathrm{z}}$ & $24 \mathrm{a}$ & $0 \mathrm{~b}$ & $8 \mathrm{a}$ \\
Hot wax & $40 \mathrm{~b}$ & $28 \mathrm{a}$ & $20 \mathrm{a}$ & $12 \mathrm{a}$ \\
Moisturin & $88 \mathrm{a}$ & $4 \mathrm{a}$ & $0 \mathrm{~b}$ & $8 \mathrm{a}$ \\
Glascol & $92 \mathrm{a}$ & $4 \mathrm{a}$ & $0 \mathrm{~b}$ & $4 \mathrm{a}$ \\
Alcoprint & $80 \mathrm{a}$ & $4 \mathrm{a}$ & $12 \mathrm{ab}$ & $4 \mathrm{a}$ \\
Probability level of contrasts & & & 0.004 & NS \\
Wax vs. antitranspirant & 0.0001 & 0.002 & $\mathrm{NS}$ \\
Control vs. all & $\mathrm{NS}$ & 0.014 & 0.002 & $\mathrm{NS}$ \\
Wax vs. all & 0.0001 & 0.010 & $\mathrm{NS}$ & $\mathrm{NS}$ \\
Control vs. antitranspirant & $\mathrm{NS}$ & 0.051 & & \\
\hline
\end{tabular}

${ }^{\mathrm{z}}$ Mean separation within columns at $P \leq 0.05$ by Tukey's Studentized Test.

injury. No damage was observed in experiments in Iowa by Foret (1951) or in New York by Tukey and Brase (1931). Under cooler establishment conditions, the wax likely cracks and falls from the canes. Waxing of canes also led to poor survival of new lateral breaks during simulated marketing (Welch and Cameron, 1990). Holding packaged roses for 4 weeks at $23 \mathrm{C}$ resulted in inferior vegetative and reproductive growth during the first season after planting.

Antitranspirants had no effect on vegetative shoot production or flowering. Desiccation stress may not have been severe enough or storage conditions were optimal (2C, high relative humidity) so moisture loss from plants before planting was minimized, and application of antitranspirants did not confer any benefit. Packaging roots of bare-root roses, a relative recent commercial practice, may have conserved enough moisture to prevent dehydration of the plants during display in the shadehouse. Earlier studies emphasized the importance of environmental conditions on efficiency and usefulness of antitranspirants (Davies and Kozlowski, 1974). Performance differences in growth between waxed and unwaxed rose plants were previously observed under conditions of high evaporation after planting, but under cool and humid weather conditions, no differences were found (Toy and Mahlstede, 1959). Hot wax treatment re- sulted in the thickest coating and was most effective in retarding weight loss of stem sections during laboratory screening; however, it also resulted in severe cane damage in the field, thus reducing vegetative growth, and cannot be recommended for bare-root roses that are shipped to destinations in the United States that can be expected to have high temperatures following planting.

\section{Literature Cited}

Coutts, M.P. 1981. Effects of root or shoot exposure before planting on the water relations, growth and survival of Sitka spruce. Can. J. For. Res. 11:703-709.

Davies, W.J. and T.T. Kozlowski. 1974. Short- and long-term effects of antitranspirants on water relations and photosynthesis of woody plants. J. Amer. Soc. Hort. Sci. 99(4):297-304.

Englert, J.M., K. Warren, L.H. Fuchigami, and T.H.H. Chen. 1993. Antidesiccant compounds improve the survival of bare-root deciduous nursery trees. J. Amer. Soc. Hort. Sci. 118(2):228-235.

Foret, J.A. 1951. Does waxing affect growth? Amer. Rose Ann. 36:185-187.

Lefevre, R.E., A.C. Cameron, and N.C. Peterson. 1991. Influence of moisture loss during storage and new growth of conifer seedlings. J. Environ. Hort. 9(2):92-96.

Lyle, E.W. 1955. Hot waxing of rose bushes for store trade. Amer. Rose Ann. 40:113-115.

Murakami, P., T.H.H. Chen, and L.H. Fuchigami. 1990. Desiccation tolerance of deciduous plants during postharvest handling. J. Environ. Hort. 8(1):22-25.

Ritchie, G.A., J.R. Roden, and N. Kleyn. 1985. Physiological quality of lodgepole pine and interior spruce seedlings: Effects of lift dates and duration of freezer storage. Can. J. For. Res. 15:636-645.

SAS Institute. 1988. SAS/STAT user's guide release 6.03 edition. SAS Inst., Cary, N.C.

Toy, S.J. and J.P. Mahlstede. 1959. Responses of rose plants to cane coating with melted paraffin wax. Iowa State College J. Sci. 33(4):475-488.

Tukey, H.B. and K. Brase. 1931. The effect of paraffining, pruning, and other storage treatments upon the growth of roses and cherry trees. Proc. Amer. Soc. Hort. Sci. 28:489-495.

Welch, C.K. and A.C. Cameron. 1990. Elevated temperatures during simulated marketing reduces field performance of packaged rose bushes. HortScience 25:677-679. 